\title{
Short Courses on Life-zone Ecology and Tropical Dendrology Offered by the Tropical Science Centre, San José, Costa Rica, March-May 1994
}

$\mathrm{T}$ he classification of Earth's ecosystems \& ecocomplexes affects almost all ecological and geographical sciences. Additionally, the identification of plants is closely related to the classification of ecosystems which on land are largely charactized by their plant components. Both the above subjects are important from the academic point of view, and are also the basis for sustainable resource management and biodiversity preservation.

L.R. Holdridge's Life-zone Ecology classification system and his Tropical Dendrology (a new system to identify plants in the forest) have been used by scientists and other professionals in the tropics for more than 30 years. Furthermore, based on the Life-zone Ecology system, several sound practical applications have been developed by the Tropical Science Centre, San José, Costa Rica, to be used in various fields, such as: rural development, sustainable resource management, watershed management, land-use capability, assessment of environmental impact, territorial zoning, and ecosystem characterization in protected areas.

Recently, The National Aeronautics and Space Agency (NASA) prepared a soils map of life-zone ecosystems that can be used to monitor and predict vegetation changes due to increase of $\mathrm{CO}_{2}$ (the so-called 'greenhouse effect'). Also, in 1992, the World Conservation Monitoring Centre
(WCMC) gave strong support to Holdridge's life-zone system by including it in their official publication entitled Global Biodiversity: Status of Earth's Living Resources. WCMC is jointly assessed by IUCN, UNEP, and WWF. Upon participation in the Life-zone Ecology Course, students will have gained enough knowledge to implement sound applications of the system on activities related to items mentioned in the preceding paragraph. After attending the Tropical Dendrology Course, students will have gained special skills enabling them to continue making progress on their own when working in their countries.

Courses last 3 weeks and will be offered from 21 March to 8 April (Dendrology), and from 25 April to 13 May (Ecology) in 1994. Costs are US $\$ 2,500$ for Dendrology and US \$2,700 for Ecology. For additional information, please contact the undersigned:

Humberto Jiménez SaA, Program Coordinator Tropical Science Center Apartado 8-3870-1000, San José, Costa Rica.

Tel.: (506) $252649 / 533267$

Fax: (506) 534963

\section{Introduction to the Asian Society for Environmental Protection (ASEP)}

$\mathrm{T}$ he Asian Society for Environmental Protection (ASEP) is an international non-profit association composed of professionals and institutions committed to the pursuit of sound management of the Asian environment and its natural resource-base concomitant to achieving sustainable development in the region. Realizing the need for a rational and broad-based approach in addressing environmental issues, ASEP, by tapping the expertise of its members and of the international network of which it forms an integral part, vigorously embarks on information exchange and dissemination activities. Its quarterly newsletter, The ASEP Newsletter, is the main vehicle by which members, and the public at large, are kept abreast of what is happening in the field of environmental management and technology in the region.

Publication in The ASEP Newsletter is open to both members and non-members. With the many excellent technical journals that are already available and between them cover scientific work on the environment rather well, the Newsletter strives to focus on environmental work as it is applied in Asia. ASEP strives to publish articles on environmental management - specifically in Newly Industrialized Economies (NIEs) and Developing Countries (DCs) - and that evaluate the application of state-of-the-art environmental concepts and technology for use in NIEs/DCs.

ASEP was founded at Augsburg, Germany, in 1984, by participants in the Workshop/Study-tour 'AsianBavarian Cooperation in Environmental Management', which was a follow-up activity for outstanding participants in the Carl Duisberg Gesellschaft's environmental management seminars held at the Asian Institute of Technology during the period 1978-82. ASEP completed the rigorous process for registration as a non-profit organization in Thailand in 1991.

In conjunction with the approaching 10 years' anniversary, plans are being initiated for convening the ASEP 10th Anniversary Symposium in December of 1994. It will be a major international event bringing together environmental experts to follow-up on regional achievements and to make plans and recommendations for future environmental measures.

The current membership of ASEP totals 162 individuals and institutions in 35 countries in the world. As would be expected, the vast majority of members are from the Asia/Pacific region. Additionally, there are 155 complimentary subscriptions of the Newsletter distributed to promote public awareness of the environmental priorities and needs in Asia.

ASEP is happy to invite interested parties to become members of the Society and to join hands with us for better management of the Asian environment, and for its wise development. Membership rates are: US $\$ 20$ (individual-annual), US $\$ 60$ (institutional-annual), US $\$ 200$ (individual-life), and US $\$ 600$ (institutional-life). New members are levied a one-time registration fee of US \$4.

All correspondence regarding the Anniversary Symposium, articles for due consideration for publication in the Newsletter, or individual or institutional membership, should be directed to the undersigned:

GÜNTER THARUN, Secretary-General

Asian Society for Environmental Protection (ASEP)

clo CDG-SEAPO

Asian Institute of Technology

GPO Box 2754

Bangkok 10501, Thailand. 